\title{
РОЗВИТОК КРИТИЧНОГО МИСЛЕННЯ В СТУДЕНТІВ ПЕДАГОГІЧНИХ ЗАКЛАДІВ ВИЩОЇ ОСВІТИ НА ЗАНЯТТЯХ ІЗ РИТОРИКИ
}

\author{
Корчова О. М. \\ кандидат педагогічних наук, \\ старший викладач кафедри украӥнської мови, \\ літератури та методики навчання \\ Глухівський наџіональний педагогічний університет імені Олександра Довженка \\ вул. Києво-Московська, 24, Глухів, Сумська область, Украӥна \\ orcid.org/0000-0002-7175-2424 \\ elena_kor_80@ukr.net
}

\section{Ключові слова:}

критичне мислення, розвиток, риторика, студенти, педагогічні заклади вищуої освіти.
У статті акцентовано на освітньому потенціалі риторики для розвитку критичного мислення студентів педагогічних закладів освіти. Узагальнено характеристики критичного мислення здобувачів вищої освіти (самостійність, аргументованість, комунікативність, рефлексивність), спроєктовано їх на навчальний зміст риторики. Наголошено на діалогізмі як дидактичному принципі, що сприяє активізації комунікативної діяльності студентів для розвитку їхнього критичного мислення на лекційних заняттях із риторики; на елементах технології розвитку критичного мислення 3 опертям на педагогічну рефлексію під час проведення практичних занять та виконання самостійної роботи 3 риторики, що забезпечується проблематизацією змісту навчання, створенням і розв'язанням проблемних ситуацій, виконанням завдань творчо-пошукового й стратегічного спрямування, що передбачають групову й колективну роботу. Відповідно до сутнісних характеристик процесу розвитку критичного мислення виокремлено дидактичні умови впровадження в освітній процес вищої школи завдань із риторики: ступеневість; формування індивідуального стилю оволодіння навчальним матеріалом; продуктивне колективне обговорення з аргументами мовця та слухачів варіантів розв'язання проблемних ситуацій; систематичність; атмосфера доброзичливості й психологічного комфорту. Обгрунтовано, що вивчення риторики 3 дотриманням дидактичних умов спонукають майбутніх учителів аналізувати будь-яку інформацію, критично осмислювати iі; дають змогу усвідомити продуктивність колективного обговорення проблеми; формують здатність бути активним учасником дискусії, аргументовано доводити власну точку зору, аналізувати ідеї інших, ухвалювати рішення, результативно здійснювати рефлексію. 3'ясовано, що наслідком освітнього процесу з риторики в контексті розвитку критичного мислення є активність студентів, удосконалення їхніх комунікативних якостей, формування інформаційної культури, самостійності, цілісного уявлення про навчальний матеріал, мотивації до активної навчально-пізнавальної діяльності. 


\title{
DEVELOPMENT OF CRITICAL THINKING IN STUDENTS OF PEDAGOGICAL INSTITUTIONS OF HIGHER EDUCATION IN RHETORIC CLASSES
}

\author{
Korchova O. M. \\ Candidate of Pedagogical Sciences, \\ Assistant Professor at the Department of Ukrainian Language, \\ Literature and Teaching Methods \\ Oleksandr Dovzhenko Hlukhiv National Pedagogical University \\ Kyevo-Moskovska str, 24, Hlukhiv, Sumy region, Ukraine \\ orcid.org/0000-0002-7175-2424 \\ elena_kor_80@ukr.net
}

Key words:

critical thinking, development, rhetoric, students, pedagogical institutions of higher education.
The article focuses on the educational potential of rhetoric for the development of critical thinking of students in pedagogical educational institutions. The characteristics of critical thinking of higher education students (independence, argumentation, communicativeness, and reflectivity) are generalized, they are projected on the educational content of rhetoric. Emphasis is placed on dialogism as a didactic principle that promotes the activation of students' communicative activities for the development of their critical thinking in rhetoric lectures; on the elements of technology for the development of critical thinking based on pedagogical reflection during practical classes and individual work on rhetoric, which is provided by problematizing the content of training, creating and solving problem situations, performing tasks of creative and strategic direction that involve group and collective work. In accordance with the essential characteristics of the process of critical thinking development, the didactic conditions for introduction of rhetorical tasks into the educational process of higher school are distinguished: gradation; formation of individual style for mastering educational material; productive collective discussion with the arguments of the speaker and listeners of options for solving problem situations; regularity; atmosphere of friendliness and psychological comfort. It is substantiated that the study of rhetoric with observance of certain didactic conditions encourages future teachers to analyze any information, to comprehend it critically; makes it possible to understand the productivity of collective discussion of the problem; form the ability to be an active participant in the discussion, to argue the own point of view, to analyze the ideas of others, to make decisions, to reflect effectively. It has been found that the consequence of the educational process of rhetoric in the context of critical thinking is to ensure the activity of students, to improve their communication skills, to form information culture, independent behavior and holistic view of educational material that motivates active learning activities.
Постановка проблеми. Сучасна система вітчизняної вищої освіти висуває нові вимоги до підготовки «конкурентоспроможного людського капіталу» (за Законом «Про вищу освіту»), тобто високорозвинених особистостей, успішних фахівців-професіоналів зі сформованим науковим світоглядом, високим рівнем загальнометодологічної культури, спроможних аргументовано висловлювати власну думку, формулювати особисте бачення ситуації, окреслювати можливі шляхи вирішення проблеми. Усе це передбачає впровадження в освітній процес професійної підготовки технологій особистісного розвитку, спрямованих на формування і вдосконалення пізнавально-інтелектуальної активності здобувачів вищої освіти, що характеризується здатністю аналізувати, зіставляти, синтезувати, вибудовувати логічні ланцюги - критично мислити 3 метою проєктування здобутих знань на можливі шляхи їх упровадження.

Проблема критичного мислення є актуальним напрямом зарубіжного (Д. Брунер, К. Мередит, Д. Рассел, Дж. Стілл, У. Скотт, К. Таврис, Ч. Темпл та ін.) та вітчизняного (Н. Березанська, О. Бєлкі- 
на-Ковальчук, Н. Бібік, І. Бондарчук. Л. Варзацька, С. Луців, О. Пометун, О. Савченко, С. Терно, О. Тягло, Т. Яковенко та ін.) наукового пошуку. У відомих педагогічних дослідженнях акцентовано на теоретичних моделях і практичних методиках розвитку критичного мислення в здобувачів освіти різних рівнів. Водночас вагомими $€$ психолого-педагогічні дослідження (Дж. Гілфорд, К. Дункер, Д. Клустер, М. Ліпман, І. Муштавинська, Р. Пауль, Д. Халперн; Т. Воропай, І. Горохова, О. Денисевич, С. Романова, О. Чуба та ін.) із питань сутнісного витлумачення феномена «критичне мислення» та значущості технологій розвитку критичного мислення в освітньому процесі.

Нині в науково-методичному просторі відомі два загальнопедагогічні підходи до розвитку критичного мислення: 1) впровадження окремої навчальної дисципліни («Критичне мислення», «Сократівський діалог», «Філософія мислення» тощо); 2) відповідна організація освітнього процесу з будь-якої дисципліни [1, с. 349]. Вважаємо доцільним другий підхід, адже окремо жодна навчальна дисципліна не має достатньо засобів для формування й розвитку будь-якої особистісної якості, особливо в сучасних умовах інтенсифікації самостійної роботи студентів.

Як один із можливих шляхів формування критичного мислення пропонуємо до розгляду навчальний контент риторики - дисципліни циклу загальної підготовки майбутніх освітян.

Мета статті - окреслити освітній потенціал риторики для розвитку критичного мислення студентів педагогічних ЗВО.

Виклад основного матеріалу дослідження. Особистісний розвиток педагога - «першого, а потім головного світоча в інтелектуальному житті школяра» (В. Сухомлинський) - нагальна проблема сьогодення, адже рівень знань вступників педагогічних 3ВО, на жаль, характеризується низхідною динамікою. Це актуалізує потребу інтенсифікації особистісного розвитку здобувача вищої освіти, що переорієнтовує педагогічні й методичні підходи до професійної підготовки, зокрема в напрямі впровадження технологій розвитку критичного мислення.

Згадки про критичне мислення фіксують філософські пошуки Сократа, Платона, Аристотеля, проте ідея розвитку критичного мислення зародилася лише наприкінці XX ст. у працях американських психологів В. Джемса та Дж. Дьюї [2, с. 4]. Дж. Дьюї називав означений феномен «рефлексивним мисленням» $\mathrm{i}$ трактував його як активний, наполегливий та ретельний розгляд людиною власних переконань, поглядів або певних знань 3 урахуванням підстав, на яких вони базуються, та подальших висновків, які вони дають змогу зробити [3, с. 90].
У межах публікації звернемося до визначення О. Пометун, за яким критичне мислення - це «окремий тип мислення, який характеризується активністю, цілеспрямованістю, самостійністю, дисциплінованістю, рефлексивністю та передбачає розвиток у процесі навчання здатності людини: визначати проблеми, аналізувати, синтезувати, оцінювати інформацію 3 будь-яких джерел, висувати альтернативи й оцінювати їх, обирати спосіб розв'язання проблеми чи власну позицію щодо неї й обгрунтовувати свої погляди, робити свідомий вибір і діяти» [3, с. 94].

Аналіз наукового доробку 3 окресленої проблеми дає змогу виокремити низку характеристик критичного мислення здобувачів освіти: 1) самостійність (ідеї, судження, переконання формуються самостійно в результаті пошуку й аналізу різноманітних відомостей); 2) аргументованість (раціональність суб'єктивних суджень зумовлюється логічними аргументами); 3) комунікативність (уміння слухати й чути, бути відповідальним за сказане слово, здатність доводити власну думку, готовність до дискусії тощо); 4) рефлексивність (спроможність до самоаналізу).

Означені характеристики можна спроєктувати й на риторику, яка не тільки зумовлює світосприйняття особистості, а й конституює його. Наголосимо, що вивчення риторики у ЗВО припадає на I-II курс, тобто юнацький вік здобувачів освіти, що «є сенситивним періодом для розвитку мислення, зокрема таких його рис, як абстрактність, критичність та творчість, що породжує потребу мати власну точку зору, схильність відстоювати ii, розмірковувати гіпотетико-дедуктивно <...>» $[4$, c. 12$]$. Саме тому навчальний зміст риторики доцільно розкривати 3 позиції риторичних моделей комунікативної діяльності, що уможливлюють органічну інкорпорацію здобувача вищої освіти до системи сучасної йому культури, забезпечують самовиявлення, самоідентифікацію, сприяють розвитку його критичного мислення.

Відповідно до постулатів критичного мислення знання не $\epsilon$ кінцевим результатом, а вихідною точкою, тому вважаємо за доцільне лекції з риторики, спрямовані на розширення, узагальнення й систематизацію знань про мову, мовлення, комунікацію як підгрунтя суб'єктсуб'єктної взаємодії, долучення до національної культури, мовно-мовленнєвої передусім, ознайомлення 3 історією ораторського мистецтва, опанування риторичних закономірностей результативної комунікації зі збереженням етико-моральних норм спілкування спрямовувати на активізацію пізнавальної діяльності майбутніх педагогів, зокрема залучати їх до вирішення проблемних ситуацій, обговорення дискусійних питань, відбору й тезування інформації з різних 
джерел із метою проголошення відомостей у групі. Усе це сприяє осмисленню й усвідомленню теорії риторики, удосконалює мисленнєво-мовленнєву діяльність майбутнього фахівця, є засобом розвитку його критичного мислення.

Активізувати комунікативну діяльність студентів на лекційних заняттях із риторики із метою розвитку критичного мислення, на нашу думку, можна шляхом впровадження діалогізму - принципу освітньої діяльності, основою якого є діалог як «загальний спосіб буття людини, що реалізовує унікальність і універсальність кожного 3 нас i утверджує гуманістичні відносини відвертості, рівності, взаєморозуміння і взаємодопомоги, поваги і довіри, співчуття і співпереживання, ініціативи і відповідальності <..> самоцінне «співбуття» людей, які реалізують своє “самобуття”» [5, с. 189]. Основи діалогової концепції, закладені Сократом, розвинені Л. Феєрбахом, не втратили значущості й донині (наукові пошуки Б. Ананьєва, М. Бахтіна, О. Бодальова, Г. Ковальова, Т. Флоренської та ін.), оскільки діалогізм, орієнтований на рівноправне спілкування, співпрацю, продуктивну взаємодію, спроєктований на професійну підготовку, не лише забезпечує усвідомлення необхідних знань, а й формує життєву самосвідомість, самостійність, творчу активність, індивідуальний комунікативний стиль, моделює міжособистісні стосунки, створює умови для самовдосконалення майбутніх фахівців. 3 огляду на це кожна людина є найвищою цінністю, існування якої грунтується на активній взаємодії в колі «людина - людина», що дає змогу зберегти гуманістично-антропоцентричні засади риторичної освіти в процесі розвитку критичного мислення.

Водночас риторика спонукає до внутрішнього діалогу, який моделює філософську рефлексію розмірковування, пізнання, самоаналіз - критичні мисленнєві операції, та формулює світоглядні принципи особистості. Відповідно, одним із проявів критичного мислення $є$ рефлексія. Педагогічна рефлексія - це здатність здобувача освіти бачити себе в освітній діяльності, спроможність поставити себе на місце учня, сприйняти проблему його очима. Наголошуємо на тому, що рефлексія має бути конструктивною, не принижувати власну гідність, а інтенсифікувати діяльність.

Елементи технології розвитку критичного мислення студентів, спираючись на педагогічну рефлексію, впроваджуємо й на практичних заняттях із риторики під час виконання низки завдань. Наприклад, ідею проблематизації змісту навчання втілюємо через:

1) аналіз та проєктування ідейно-тематичного змісту афоризмів на комунікативні ознаки мовлення, що дає змогу критично осмислити навчальний (лекційний) матеріал:
Чи погоджуєтеся Ви з тим, щ⿻о... Аргуменmyüme!

- Уміти правильно говорити ... щее не заслуга, а не вміти - уже ганьба, тому що правильне мовлення, по-моєму, не стільки достоӥнство вправного оратора, скільки властивість кожного громадянина (Цицерон);

- Якшуо ви розмовляєте з людиною мовою, яку вона розуміє, слова досягають ї̈ голови. Якщо ви розмовляєте з людиною ї̈ мовою, то слова досягають серия (Н. Мандела);

- Дієвий засіб змусити слухати себе - ие сказати багато в небагатьох словах (П. Буаст);

2) неоднозначність інтерпретації фактів, що сприяє формуванню здатності аналізувати, порівнювати, узагальнювати, логічно й аргументовано викладати власні думки, розпізнавати суперечливі судження:

- Чи погоджуєтеся Ви зі словами Г. Лейбніцуа: «Усяка правильна думка має бути обтрунтована іншими думками, істинність яких уже доведена»?

Доповнити, конкретизувати здобуті на лекції відомості дають змогу завдання на добір ілюстративної інформації, переконливих аргументів у контексті вирішення дискусійних питань або проблемних ситуацій, наприклад:

- Підготуйтеся до відкритого діалогу «Найрезультативніший стиль професійно-педагогічного спілкування».

- Укладіть диферениійну схему «Переваги та недоліки мережевої академічної риторики». Підготуйтеся до ї̈ коментування.

Наступні завдання вирізняються стратегічним спрямуванням, формують спроможність майбутніх фахівців реалізовувати критичне мислення під час розв'язання професійних задач, наприклад:

- Проаналізуйте початок розмови батьків учня й учителя. Передбачте можливий розвиток діалогу. Думку аргументуйте. Змоделюйте власну комунікативну стратегію в подібній ситуації.

- Наша дитина - геній! У нього стільки оригінальних ідей!

- Так, - відповідає вчитель, - особливо в правописі.

Комунікативність як одна 3 характеристик критичного мислення має соціальну природу, що передбачає групову й колективну роботу з елементами дослідницького пошуку, що простежуються у завданнях творчо-пошукового спрямування, наприклад:

- Підготуйтеся до дискусї «Мова - засіб консолідащіï чи розбрату в суспільстві» відповідно до вибраної мовної ролі: мовецьь, який стверджує тезу 1 «мова - засіб консолідації»; мовець, який стверджує тезу 2 «мова - засіб розбрату»; ведучий - керівник дискусї; експерт (теза 1); експерт (теза 2); логік (з'ясовує супе- 
речності й логічні помилки у виступах, аналізує тактику учасників дискусіі); рецензент (аналізує дотримання морального кодексу та мовленнєвого етикету учасниками дискусії); активний слухач; психолог (не допускає перетворення дискусіі на конфлікт; аналізуе дотримання культури критики та компліменту); лінгвіст (аналізує дотримання комунікативних ознак мовлення всіма учасниками дискусії).

Завдання такого типу сприяють удосконаленню мисленнєвих операцій здобувачів освіти, а саме: порівняння, узагальнення, абстрагування, систематизації, конкретизації, що формують здатність ставити мету, бачити проблему, окреслювати шляхи іiі вирішення, аргументувати власну точку зору, аналізувати альтернативні судження, ухвалювати рішення.

Розвитку критичного мислення також сприяє самостійна робота з риторики, що передбачає:

- усвідомлений розгляд різних підходів із метою пошуку істини (причому завдання змодельоване за зразком аудиторних, що полегшує студентам його виконання), наприклад:

Чи погоджуєтеся Ви з тим, щзо... Аргуменmуйте! Спроєктуйте ідейно-тематичний зміст афоризмів на труднощі спілкування.

а) Різниця між правильним словом $і$ майже правильним словом подібна до різниці між блискавкою і жуком-світляком (М. Твен);

б) Природа дала нам один язик і два вуха, ичоб ми могли слухати вдвічі більще, ніж говорити (Enіктет);

в) Щоб спілкуватися ефективно, ми маємо зрозуміти, щзо ми всі по-різному сприймаємо світ (Е. Робінс);

- укладання опорних схем і таблиць теоретичного матеріалу, винесеного на самостійне опрацювання, або доповнення лекційних відомостей замість написання конспектів, адже ланцюговий або радіальний запис інформації, на відміну від лінійного, дає змогу простежити логічні, причинно-наслідкові, асоціативні зв'язки підтем, акцентувати на головному, наприклад:

- Укладіть опорну схему або таблицюю на одну з тем (за Вашим вибором): «Зовнішня культура оратора», "Гендерні аспекти спілкування», "Елементи міжкультурної комунікаиії в академічному просторі». Підготуйтеся до ї̈ коментування;

- аналіз інформації з позицій логіки 3 метою формулювання аргументованих суджень, наприклад:

- Чи погоджуєтеся Ви з тим, щзо запропоновані характеристики є найтиповішими помилками полеміста. Якщо ні, відкоригуйте список; якщзо так, диферениіюйте ознаки на небажані та загрозливі. Власну думку аргументуйте: виправдання перед слухачами; невідповідність вербаль- них і невербальних засобів спілкування; занадто довгі паузи, «екання» під час викладу думки; суворий вираз обличчя; метушливість; «усезнаюча» пафосність; монотонність мовлення; занадто швидкий або занадто повільний темп мовлення; «неунаочненість» викладу (без прикладів, зображень, розрахунків тощуо); читання підготовленого матеріалу.

Загалом самостійна робота студентів із риторики, орієнтована на систематизацію, узагальнення й поглиблення набутих теоретичних знань та практичних умінь, містить завдання різного типу: від опрацювання теоретичного матеріалу, виконання вправ на вдосконалення комунікативної вправності, розвиток умінь і навичок ритора й адресата ораторського мовлення до творчих завдань (моделювання аудіовізуальних матеріалів, виступ-презентація, захист мініпроєкту тощо), спрямованих на розвиток творчих потенцій студентів із метою оволодіння культурою й технікою мовлення та основними засадами публічного мовлення: принципами, правилами, формами взаємодії ритора й слухача засобами промови. Такі завдання дають змогу аналізувати, систематизувати, структурувати навчальний матеріал, критично осмислювати його.

Відповідно до сутнісних характеристик процесу розвитку критичного мислення можемо виокремити дидактичні умови впровадження в освітній процес вищої школи описаних завдань із риторики:

- ступеневість (пояснення викладачем, колективне виконання, самостійне виконання);

- формування індивідуального стилю оволодіння навчальним матеріалом (наприклад, укладання опорних схем, написання та проголошення промов тощо), що дає змогу адаптувати навчальний матеріал до індивідуальних особливостей мислення кожного студента;

- продуктивне колективне обговорення з аргументами мовця і слухачів варіантів розв'язання проблемних ситуацій (дискусія, конкурс-презентація тощо), що сприяє вдосконаленню причинно-наслідкових зв'язків між ключовими поняттями навчального матеріалу;

- систематичність застосування, що уможливлює впровадження студентами таких освітніх технологій у майбутню педагогічну діяльність;

- атмосфера доброзичливості й психологічного комфорту, що забезпечує вільний мисленнєво-мовленнєвий процес.

Висновки. Отже, описані завдання 3 дотриманням дидактичних умов їх упровадження під час вивчення риторики спонукають майбутніх фахівців аналізувати будь-яку інформацію, критично осмислювати іï, дають змогу усвідомити продуктивність колективного обго- 
ворення проблеми, формують здатність бути активним учасником дискусії, аргументовано доводити власні міркування, аналізувати ідеї інших, ухвалювати рішення, результативно здійснювати рефлексію. Розвиток критичного мислення забезпечує активність студентів під час освітнього процесу, розвиває їхні комунікативні якості, формує інформаційну культуру, самостійність, цілісне уявлення про навчальний матеріал, мотивує до активної навчально-пізнавальної діяльності.

Окреслену проблему не можна вважати повною мірою вирішеною, оскільки зміст, форми, методи й технології формування критичного мислення потребують постійного оновлення відповідно до суспільного розвитку.

\section{Література}

1. Луців С. Педагогічні умови формування критичного мислення учнів початкових класів на уроках української мови. Актуальні питання гуманітарних наук. Педагогіка. 2016. Вип. 16. С. 347-352.

2. Терно С.О. Розвиток критичного мислення старшокласників у процесі навчання історії. Запоріжжя : Запорізький національний університет, 2011. 275 с.

3. Пометун О.І. Критичне мислення як педагогічний феномен. Украӥнський педагогічний журнал. 2018. № 2. C. 89-98.

4. Терно С.О. Методика розвитку критичного мислення старшокласників у процесі навчання історії : автореф. дис. ... д-ра пед. наук : 13.00.02. Київ. 2015. 40 с.

5. Дьяконов Г.В. Активні методи групового навчання: діалогічний підхід. Педагогіка вищої та середньої школи. 2012. № 35. С. 188-197. URL: http://nbuv.gov.ua/UJRN/PVSSh_2012_35_27. (дата звернення: 24.08.2020)

\section{References}

1. Lutsiv, S. (2016) Pedagogichni umovi formuvannya kritichnogo mislennya uchniv pochatkovih klasiv na urokah ukrayinskoyi movi [Pedagogical conditions of critical thinking of primary school at the Ukrainian language lessons]. Humanities science current issues. Vol. 16. P. 347-352.

2. Terno, S.O. (2011) Rozvitok kritichnogo mislennya starshoklasnikiv u protsesi navchannya istoriyi [The Development of Senior Pupils' Critical Thinking in History Teaching Process]. Zaporizhzhya: Zaporizhzhya National University. 275 p.

3. Pometun, O. (2018) Kritichne mislennya yak pedagogichniy fenomen [Critical thinking as a pedagogical phenomenon]. Ukrainian educational journal. Vol. 2. P. 89-98.

4. Terno, S.O. (2015) Metodika rozvitku kritichnogo mislennya starshoklasnikiv u protsesi navchannya istoriyi [The Development Strategy of Senior Pupils' Critical Thinking in History Teaching Process]: Abstract of Doctor's thesis (Pedagogi). Kyiv, $40 \mathrm{p}$.

5. Diakonov, H.V. (2012) Aktivni metodi grupovogo navchannya: dialogichniy pidhid [Active methods of group learning: a dialogical approach]. Higher and secondary school pedagogy. Vol. 35. P. 188-197. URL: http://nbuv.gov.ua/UJRN/PVSSh_2012_35_27. 